Article

\title{
Sustainable Consumption in Consumer Behavior in the Time of COVID-19: Topic Modeling on Twitter Data Using LDA
}

\author{
Paweł Brzustewicz * (D) and Anupam Singh \\ Department of Organizational Behavior and Marketing, Faculty of Economic Sciences and Management, \\ Nicolaus Copernicus University, 87-100 Torun, Poland; anupam.nitb@gmail.com \\ * Correspondence: pbrzustewicz@umk.pl
}

Citation: Brzustewicz, P.; Singh, A. Sustainable Consumption in Consumer Behavior in the Time of COVID-19: Topic Modeling on Twitter Data Using LDA. Energies 2021, 14, 5787. https://doi.org/ $10.3390 /$ en14185787

Academic Editors: David Borge-Diez and Abu-Siada Ahmed

Received: 9 August 2021

Accepted: 10 September 2021

Published: 14 September 2021

Publisher's Note: MDPI stays neutral with regard to jurisdictional claims in published maps and institutional affiliations.

Copyright: (c) 2021 by the authors. Licensee MDPI, Basel, Switzerland. This article is an open access article distributed under the terms and conditions of the Creative Commons Attribution (CC BY) license (https:/ / creativecommons.org/licenses/by/ $4.0 /)$.

\begin{abstract}
By using text mining techniques, this study identifies the topics of sustainable consumption that are important during the COVID-19 pandemic. An Application Programming Interface (API) streaming method was used to extract the data from Twitter. A total of 14,591 tweets were collected using Twitter streaming API. However, after data cleaning, 13,635 tweets were considered for analysis. The objectives of the study are to identify (1) the topics users tweet about sustainable consumption and (2) to detect the emotion-based sentiments in the tweets. The study used Latent Dirichlet Allocation (LDA) algorithm for topic modeling and the Louvain algorithm for semantic network clustering. NRC emotion lexicon was used for sentiment analysis. The LDA model discovers six topics: organic food consumption, food waste, vegan food, sustainable tourism, sustainable transport, and sustainable energy consumption. While the Louvain algorithm detects four clusters-lifestyle and climate change, responsible consumption, energy consumption, and renewable energy, sentiment analysis results show more positive emotions among the users than the negative ones. The study contributes to existing literature by providing a fresh perspective on various interconnected topics of sustainable consumption that bring global consumption to a sustainable level.
\end{abstract}

Keywords: sustainable consumption; consumer behavior; COVID-19; coronavirus; Twitter; Latent Dirichlet Allocation (LDA); machine learning; semantic analysis; semantic network analysis; sentiment analysis

\section{Introduction}

Pandemics (infectious disease outbreaks of a worldwide reach) have struck humankind many times in recent years. When considering only the last 20 years, pandemics such as SARS (2003), MERS (2012-present), Swine flu (2009-2010), Ebola (2014-2016), Zika (2015-2016), and COVID-19 (2019-present) can be mentioned. Compared to other major pandemics, both the scale and economic and social consequences of COVID-19 are significantly greater. The COVID-19 pandemic has influenced 220 countries with more than 195 million confirmed cases and over 4.1 million deaths worldwide to date [1]. The pandemic has impacted many areas of life, including healthcare systems, economic and financial security, wellbeing, work, trade, travel and tourism, transportation, agriculture, and food security across the world [2-6]. According to World Health Organization [2], as a result of the pandemic, tens of millions of people are at risk of losing their livelihoods and falling into extreme poverty; the number of undernourished people has increased considerably; and border closures and other restrictions have been preventing businesses from accessing markets. It has also been confirmed that the COVID-19 pandemic has led to changes in human behavior, including consumer behavior and consumption patterns; it has influenced lifestyles, buying intentions and behaviors, wants, and the way goods and services are consumed [7-10].

During the coronavirus pandemic, changes in consumer behavior may affect different aspects of such behavior, including food purchasing, spending patterns, consumption 
habits, shift to online purchasing etc. [11-17]. Although it is impossible to identify all of them, due to the growing interest in health issues during the pandemic, consumer behavior is evolving towards healthier and more sustainable patterns [3,18]. Among these publications, studies on the impact of the pandemic on sustainable consumption have a large share [19-23]. In various publications, different aspects of such behavior are analyzed in the context of the COVID-19 pandemic, for example: eating a healthier diet [18,24], buying local [18], environmental awareness [20,25], or negative emotions [21].

Thus, most of the publications on sustainable consumption during coronavirus pandemic have been devoted to the analysis of individual issues in this area. In contrast, still, publications in which a more holistic and integrating approach is used, showing which topics (aspects) of sustainable consumption remain important for consumers, are few $[23,26]$. Meanwhile, knowledge about sustainable consumption behavior is a key element in implementing the concept of sustainable development, which involves departing from traditional consumption patterns towards a more sustainable model $[19,27]$. Understanding which topics in the field of sustainable consumption are relevant to consumers during COVID-19 seems extremely important, both for businesses and various institutions involved in achieving sustainable development goals. Companies can use such knowledge not only to meet customer needs better but also to do so in a sustainable manner.

Similarly, different institutions can use knowledge in this field, e.g., to shape more responsible consumption patterns in society. Moreover, to our knowledge, this article is one of the first publications to deal with the topic modeling technique to understand and extract such hidden aspects of sustainable consumption from Twitter data. Moreover, the use of big data in the study of consumer behavior is not frequent, while processing and analysis of big data are precious because it enables to obtain new, beneficial information [28]. In order to fill this gap, we pose the following research question in the article: What topics of sustainable consumption are of importance to Twitter users in the time of the COVID-19 pandemic?

The aim of this article is to identify which topics in the area of sustainable consumption are most important to consumers in the time of COVID-19. This study used Twitter data and sophisticated machine learning algorithms for topic extraction, semantic network clustering, and LDA-based topic modeling implemented in the R package "topicmodels". The results confirm the presence of six topics in our corpus. Furthermore, the Louvain algorithm was applied to detect semantic clusters. The network graph shows the presence of four clusters in our text data. Finally, emotion-based sentiments in tweets are analyzed using the NRC lexicon.

The rest of this paper is organized as follows: Section 2 provides a review of pertinent literature on consumer behavior and sustainable consumption. Following that, Section 3 discusses the materials and methods. Then, in Section 4, the results of the analysis are presented. In Section 5, the findings are discussed. Section 6 concludes the study with its implications, limitations, and future research directions.

\section{Theoretical Background}

\subsection{Nature of Consumer Behavior}

Consumer behavior consists of the activities and experiences of people involved in buying, using, and disposal of goods and services [27]. The classic model of consumer behavior consists of three elements: stimuli (marketing and non-marketing), consumer awareness, and purchase decisions [29]. The basic marketing stimuli that companies use to influence consumer awareness consist of product, price, place, and promotion. The decision to buy (or not) is additionally shaped by two elements that constitute consumer's awareness: the buyer's characteristics and the buying decision process. The consumer decision process is composed of problem recognition, information search, alternative evaluation, purchase, and post-purchase behavior [29].

Nowadays, an increasing number of consumers recognize that their buying behavior has a negative impact on both the environment and society [30-32]. The main repercussions 
of such impact include depletion of natural resources, climate change, increased environmental pollution, and depletion of flora and fauna [30,33]. Depending on the spectrum of issues motivating their buying behavior, this specific group of consumers is called green, ethical, socially responsible, or sustainable consumers [34]. A green consumer is defined as a person who, when meeting needs, considers the effect on the ecosystem [35]. Green consumers are also referred to as eco-consumers [36], eco-conscious consumers [37], environmentally conscious consumers [38], eco-friendly consumers [39], and environmentally responsible consumers [40]. An ethical consumer is defined as a person whose consumption behavior is determined by moral values and norms [41]. A socially responsible consumer can be defined as one whose decisions are simultaneously economically, ecologically, and socially responsible [42]. Similarly, a sustainable consumer can be defined as a person who expresses concerns about sustainability issues and reflects those concerns in their consumption choices and behaviors [43].

When making decisions about meeting needs and wants, sustainable consumers consider what to buy and whether to purchase it or not [44]. Contrary to consumers with low environmental and social awareness, they avoid buying products on impulse, which can be unnecessary, burden the environment, and negatively impact society [31,45]. Sustainable consumers consider the consequences of their individual choices in their purchasing decisions, choosing environmentally and socially effective products [46].

A variety of factors determine sustainable consumer behavior. These factors can be analyzed at micro, meso, and macro levels, depending on the purpose of the analysis [47]. Various researchers have analyzed the influence of multiple factors on sustainable consumer behavior, including, among others: economic, technological, political, cultural, social, personal, and psychological factors [30,31,48-52].

Sustainable consumer behavior is concerned with understanding both how buying decisions are made and how products are consumed. Consumption is not only a social process but also a physical activity in which resources are consumed. What people eat, how they heat their homes, and how they travel have serious social and environmental consequences for individuals, countries, and the planet as a whole [43].

\subsection{Various Facets of Sustainable Consumption}

From a marketing perspective, consumption is a mechanism that benefits the individual consumer [53-55]. Although consumption is indispensable for human life, some of its patterns may harm the ecosystem and society. In the era of climate change, resource depletion, excessive water and air pollution, and problems with hazardous waste, it is necessary to change the consumption model to a more sustainable one $[43,46,56,57]$.

Despite the large number of definitions of sustainable consumption presented in the literature, they often differ significantly, both regarding the level of analysis of this phenomenon and terminology. One of the most frequently cited definitions is the one proposed by the Norwegian Ministry of Environment at the Oslo Roundtable on Sustainable Production and Consumption held in 1994. According to it, sustainable consumption is "the use of goods and services that respond to basic needs and bring a better quality of life, while minimizing the use of natural resources, toxic materials, and emissions of waste and pollutants over the life cycle, so as not to jeopardize the needs of future generations" [58] (p. 11). Other definitions of sustainable consumption most often refer to the above mentioned proposition. For example, The United Nations Environment Programme (UNEP) states that sustainable consumption is "a holistic approach to minimizing the negative environmental impacts from consumption and production systems while promoting quality of life for all" [59] (p. 10). Sustainable consumption is an important element of "The 2030 Agenda for Sustainable Development', outlined by the UN in 2015, in which goal 12 is devoted to the issue of responsible consumption and production [60]. The UN explains that "sustainable consumption and production is about doing more and better with less. It is also about decoupling economic growth from environmental degradation, increasing resource efficiency and promoting sustainable lifestyles. Sustainable consumption and production can also 
contribute substantially to poverty alleviation and the transition towards low-carbon and green economies" [61].

The concept of sustainable consumption connects a number of topics, such as needs and wants, wellbeing, efficiency, waste management, and life cycle perspective [62]. From a macro perspective, sustainable consumption requires a radical change of the current model of using resources, reducing waste and pollution, as well as redefining the quality of life concept. Whereas from a business perspective, sustainable consumption demands taking sustainable actions at all stages of the life cycle of goods and services, which in the literature is often reflected in "cradle-to-cradle" or "cradle-to-grave" approaches [63].

Departure from unsustainable consumption will not succeed without collaboration in this area at global, national, regional and local levels. Sustainable consumption needs collaboration between international institutions, governments, as well as companies and customers [46,64-66]. Achieving more sustainable consumption requires structural changes involving both consumer behavior and business performance $[67,68]$. According to the UN, "innovative, concerted efforts to decouple economic growth from natural resource depletion and environmental degradation are needed, which will require social and technological innovation, new policies and policy reforms, public and private investments, multi-stakeholder cooperation, and improved private-sector management practices. Reorienting consumer choices and lifestyles will also have a crucial role to play" [64] (p. 9). Thus, the implementation of sustainable consumption patterns is not possible without the simultaneous effort of various actors and changing the functioning of entire structures, including society, business, and public institutions.

Sustainable consumption is an umbrella term that encompasses a number of different topics. A report generated from the Scopus database for the term "sustainable consumption" [TITLE-ABS-KEY ("sustainable consumption")] contains as many as 2892 publications (as of 20 July 2021) that meet the above criteria. The retrieved publications discuss various topics related to sustainable consumption. Only in 2021 these topics included, among others: using electric vehicles [69], energy consumption [70], water consumption [71], food consumption [72], reducing wastes [73], sustainable fashion [74], using product packaging [75], sharing economy [76], sustainable tourism [77], sustainable housing [78], and sustainable cities [79].

Table 1 presents the 10 most frequently cited articles with the term "sustainable consumption" in the title, abstract, or keywords.

The most cited article [80] uses a systematic review approach to formalize a categorization of business model innovations to deliver sustainability. Most of the business models identified by the authors of the paper have the potential to reduce resource consumption or consumption patterns. The second article [81] focuses on the gap between favorable attitude towards sustainable behavior and behavioral intention to purchase sustainable food products. The third article [82] quantifies and maps the water footprint of humanity (per country) from both a production and consumption viewpoint. The fourth paper [83] explores the buying process for eco-friendly consumers in relation to consumer technology products in the United Kingdom. The fifth paper [84] discusses product-service systems encapsulating the analysis conducted in the book 'New Business for Old Europe', diverse EU sponsored projects, and the theoretical attitude chosen in a research network on Sustainable Consumption and Production. The sixth article [85] discusses the water footprint of animal products, taking into account various production systems and feed composition per livestock category and nation. The seventh article [86] focuses on food waste factors and presents a framework to determine the most suitable alternatives for prevention and management of food waste. The eighth article [87] examines personal and contextual barriers to consumers' purchases of green food in Switzerland. The ninth article [88] investigates determinants of sustainable food consumer behavior in Belgium. The less cited article [89] applies social practice theory to the study of green behavior change using ethnographic research. 
Table 1. Most cited papers with the term 'sustainable consumption'.

\begin{tabular}{|c|c|c|c|}
\hline Title & $\begin{array}{l}\text { Author(s) and Year of } \\
\text { Publication }\end{array}$ & Source Title & Number of Citations \\
\hline $\begin{array}{l}\text { A literature and practice review to } \\
\text { develop sustainable business model } \\
\text { archetypes }\end{array}$ & Bocken et al., 2014 & Journal of Cleaner Production & 1175 \\
\hline $\begin{array}{l}\text { Sustainable food consumption: } \\
\text { Exploring the consumer } \\
\text { "attitude-Behavioral intention" gap }\end{array}$ & Vermeir \& Verbeke, 2006 & $\begin{array}{l}\text { Journal of Agricultural and } \\
\text { Environmental Ethics }\end{array}$ & 1116 \\
\hline The water footprint of humanity & Hoekstra \& Mekonnen, 2012 & $\begin{array}{l}\text { Proceedings of the National } \\
\text { Academy of Sciences of the } \\
\text { United States of America }\end{array}$ & 1086 \\
\hline $\begin{array}{c}\text { Sustainable consumption: Green } \\
\text { consumer behaviour when } \\
\text { purchasing products }\end{array}$ & Young et al., 2010 & Sustainable Development & 675 \\
\hline $\begin{array}{l}\text { Product-services as a research field: } \\
\text { past, present and future. Reflections } \\
\text { from a decade of research }\end{array}$ & Tukker \& Tischner, 2006 & Journal of Cleaner Production & 577 \\
\hline $\begin{array}{l}\text { A global assessment of the water } \\
\text { footprint of farm animal products } \\
\text { The food waste hierarchy as a }\end{array}$ & Mekonnen \& Hoekstra, 2012 & Ecosystems & 557 \\
\hline $\begin{array}{l}\text { framework for the management of } \\
\text { food surplus and food waste } \\
\text { Promoting Sustainable }\end{array}$ & Papargyropoulou et al., 2014 & Journal of Cleaner Production & 505 \\
\hline $\begin{array}{c}\text { Consumption: Determinants of } \\
\text { Green Purchases by Swiss } \\
\text { Consumers }\end{array}$ & Tanner \& Kast, 2003 & Psychology and Marketing & 502 \\
\hline $\begin{array}{l}\text { Sustainable food consumption } \\
\text { among young adults in Belgium: } \\
\text { Theory of planned behaviour and } \\
\text { the role of confidence and values }\end{array}$ & Vermeir \& Verbeke, 2008 & Ecological Economics & 475 \\
\hline $\begin{array}{l}\text { Practice-ing behaviour change: } \\
\text { Applying social practice theory to } \\
\text { pro-environmental behaviour } \\
\text { change }\end{array}$ & Hargreaves, 2011 & Journal of Consumer Culture & 474 \\
\hline
\end{tabular}

\section{Materials and Methods}

This section introduces the integrated framework for data collection method, data cleaning/pre-processing, and text mining approaches for analysis. The schematic framework (Figure 1) presents the methodological architecture of the study.

As shown in Figure 1, the first stage involved the acquisition of data. Twitter was chosen as a data source for this study. Tweets were collected using the streaming API method. In the second stage, the text data (tweets) obtained in the first stage was preprocessed for the final analysis (please refer to the "Data collection and pre-processing" section for more detail). The third stage involved data analysis. A number of different text mining techniques were used for the analysis, such as topic modeling for identifying the latent topics in the text data; semantic network analysis for visualizing the semantic relationships between words in the corpus; and sentiment analysis for identifying emotions and sentiments. 


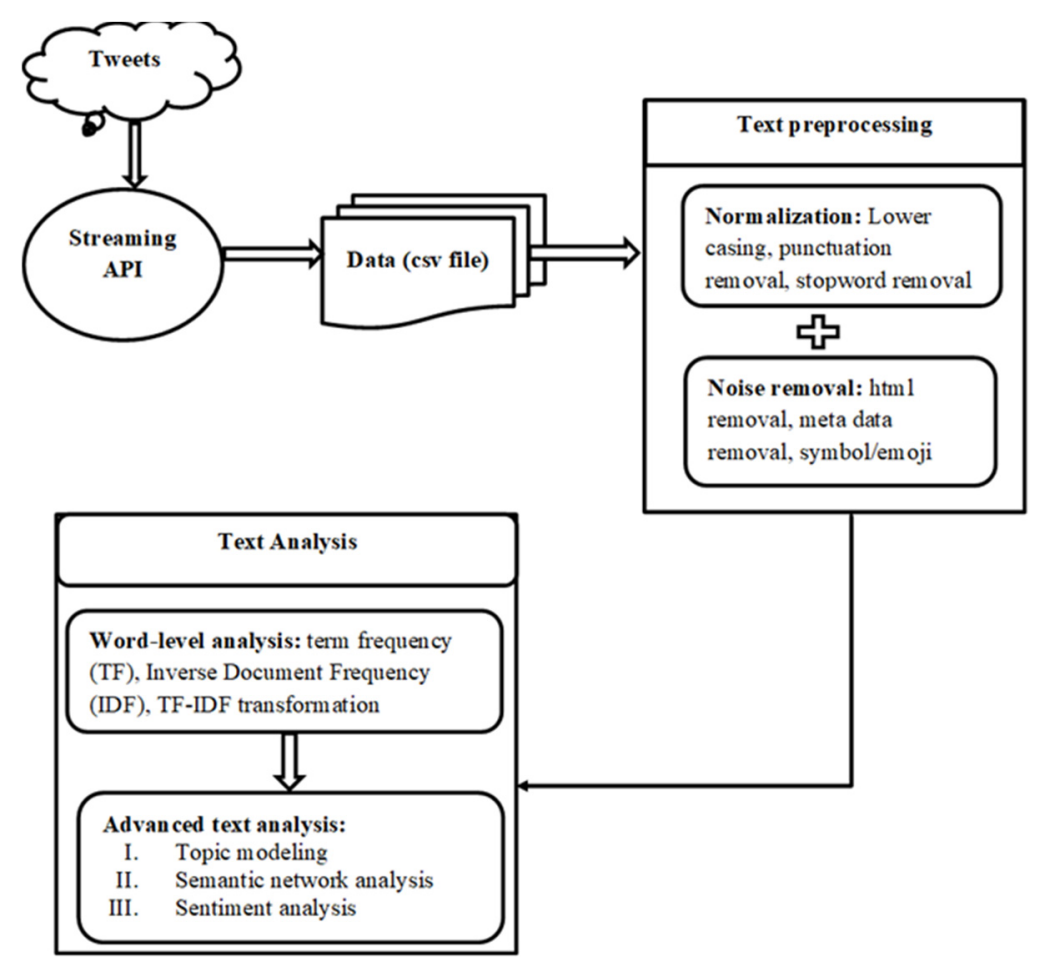

Figure 1. A schematic framework of text data analysis method.

\subsection{Data Collection and Pre-Processing}

Over the past years, social networking sites (SNS) such as Facebook, Twitter, MySpace, FriendFeed, and GooglePlus have revolutionized the way people communicate with each other across the world. Moreover, these SNS platforms leave massive real-time data for researchers from different fields such as linguistics, sociology, behavioral sciences, health, and psychology. Twitter is one of the most popular social media today, connecting over 650 million registered users [90]. The conversations on Twitter are publicly available and easily accessible through Twitter's Application Programming Interface (API). Therefore, Twitter was chosen as the data source for this study.

The R programming language was used for streaming data and analysis. Twitter posts were extracted using the Twitter Streaming API, where 14,591 tweets were extracted using the search key term "sustainable consumption" from a period between 1 July 2021 and 15 July 2021. After removing the duplicates, 13,635 tweets remained. Twitter data is usually unstructured and noisy; therefore, it was pre-processed before the main analyses. The " $\mathrm{tm}$ " package, a framework for text mining applications within $\mathrm{R}$ for managing text documents, was used for this purpose. Using the "tm" package, we improved the content of our corpus. The stuff in the corpus that did not serve any meaning was removed first, such as numbers, URLs, punctuations, and stop words, followed by whitespace removal.

\subsection{Text Mining Approaches}

\subsubsection{Topic Modeling}

Latent Dirichlet Allocation (LDA)-based topic modeling is used in the present study. It is a generative probabilistic model based on a three-level hierarchical Bayesian model [91]. The method has been used in a wide range of fields and has the highest performance among several topic modeling algorithms with proven reliability [92]. For the implementation of LDA, 'topicmodels', a package for topic modeling, is utilized.

LDA is an unsupervised learning algorithm that discovers latent topics based on patterns of cooccurrences of words in the corpus. The basic underlying idea behind LDA modeling is that each of $D$ documents is a mixture over $K$ latent topics. Furthermore, each topic is a multinomial distribution of $\mathrm{W}$ words vocabulary. $\varphi_{k}(\forall k=1, \ldots, K)$ is the probabilistic distribution over words of each latent topic, $\varphi_{k} \theta_{d}(\forall d=1, \ldots, M)$ is 
per-document topic distribution, $M$ is number of documents, and $N$ is number of words in the vocabulary. $\alpha$ and $\beta$ are Dirichlet, where $\alpha$ represents per-document topic distributions, and $\beta$ represents per-topic word distribution. For each document $d$ in the corpus, the words are generated in a two-stage process. A distribution over topics is randomly chosen in the first stage. Based on this distribution, a topic from the distribution over topics is randomly chosen for each word of the document.

LDA assumes that each document exhibits the topics in a different proportion; each word in each document is drawn from one of the topics, where the selected topic is chosen from the per-document distribution over topics. In the second stage, the unobserved variables $\varphi_{k}$ and $\theta_{d}$ are generated through Gibbs sampling probability distribution $p(D \mid \alpha, \beta)$. Thus, the generative process of the LDA model for a corpus can be obtained by taking the product of the marginal probabilities of single documents.

$$
p(D \mid \alpha, \beta)=\prod_{d=1}^{M} \int P\left(\theta_{d} \mid \alpha\right)\left(\prod_{n=1}^{N_{d}} \sum_{z_{\mathrm{d}_{n}}} P\left(z_{d_{n}} \mid \theta_{d}\right) P\left(w_{\mathrm{d}_{n}} \mid z_{\mathrm{d}_{n}}, \beta\right)\right) \mathrm{d} \theta_{d}
$$

\subsubsection{Semantic Network Analysis}

Semantic analysis is a subfield of Natural Language Processing (NLP) and Machine Learning that performs the task of building structures that approximate concepts in the corpus of a large set of documents. Semantic network analysis is an interactive visual analysis system that describes semantic networks of words in a corpus. The network structure consists of nodes and edges, each word is represented by a node, and the edges represent semantic ties between words.

We applied the Louvain Community Detection Algorithm (LCDA) to detect semantic clusters. This approach maximizes a modularity score for each cluster, where the modularity quantifies the quality of an assignment of nodes to clusters. The method evaluates how much more densely connected nodes are within a cluster as compared to connections in a random network. The inspiration for the Louvain algorithm of clustering is to optimize the modularity. Modularity is a scale that measures the strength of the relative density of edges inside the network. The value lies in the range $[-0.5,1]$. The modularity function measures the strength of dividing a network into clusters. For every node in a network, the modularity value $\Delta Q$ is computed for all neighboring clusters:

$$
\Delta Q=\left[\frac{\Sigma_{i n}+2 k_{i, i n}}{2 m}-\left(\frac{\Sigma_{t o t}+k_{i}}{2 m}\right)^{2}\right]-\left[\frac{\Sigma_{i n}}{2 m}-\left(\frac{\Sigma_{t o t}}{2 m}\right)^{2}-\left(\frac{k_{i}}{2 m}\right)^{2}\right]
$$

where $\Sigma_{i n}$ is the sum of all the weights within the cluster to which the node $i$ is assigned, $\Sigma_{t o t}$ is the sum of all the weights of the links associated with the nodes moving into cluster $i, k_{i, i n}$ is the sum of the weights of the links from node $i$ to other nodes in the cluster that $i$ is moving into, $k_{i}$ is the sum of the weights of the links incident to node $i$, and $\mathrm{m}$ is the sum of the link's weights in the network.

\subsubsection{Sentiment Analysis}

Sentiment analysis (SA) is a technique of identifying and extracting the sentiment associated with a piece of text data. It is an area of computational linguistics and NLP that analyses subjective information such as opinions and emotions expressed in the text [93]. Two primary methods (lexicon-based and corpus-based) are available for conducting SA. The lexicon-based method of sentiment analysis was adopted in this study. To date, several lexicons are available to perform sentiment analyses, such as the SentiWordNet, General Inquirer, the Q-WordNet, the lexicon of Subjectivity Clues, the LIWC dictionary, and the Sentiment-based Lexicon [94]. We preferred to use NRC lexicon over other available lexicons as it is capable of classifying emotions into eight basic categories: anger, fear, sadness, anticipation, disgust, joy, surprise, and trust, apart from identifying positive and negative sentiments in the data. 


\section{Results}

\subsection{LDA Model}

Before LDA topic modeling, we conducted perplexity and coherence tests to evaluate our model. Perplexity is a measure of the quality of the entire model [91]. It measures how well a model describes a document according to a generative process based on the learned set of topics. In contrast, topic coherence captures the optimal number of topics based on the degree of semantic similarity between high scoring words within the topic; thereby giving the human interpretable topics. Table 2 presents perplexity scores from topics 1-15. A low perplexity indicates that the probability distribution is good at predicting the document. An optimal number of topics is obtained based on perplexity validation, where the score hits bottom before rising. The model with six topics has the lowest perplexity score (see Table 2). Thus, a model with six topics is identified as the most reliable model compared to any other in our data.

Table 2. Perplexity values for different numbers of topics.

\begin{tabular}{cccccc}
\hline $\begin{array}{c}\text { Number } \\
\text { of Topics }\end{array}$ & $\begin{array}{c}\text { Validation } \\
\text { Perplexity }\end{array}$ & $\begin{array}{c}\text { Number } \\
\text { of Topics }\end{array}$ & $\begin{array}{c}\text { Validation } \\
\text { Perplexity }\end{array}$ & $\begin{array}{c}\text { Number } \\
\text { of Topics }\end{array}$ & $\begin{array}{c}\text { Validation } \\
\text { Perplexity }\end{array}$ \\
\hline 1 & 271.2 & 6 & 230.9 & 11 & 266.2 \\
2 & 269.2 & 7 & 238.2 & 12 & 270.9 \\
3 & 266.3 & 8 & 245.5 & 13 & 274.6 \\
4 & 255.5 & 9 & 254.4 & 14 & 271.8 \\
5 & 245.8 & 10 & 258.9 & 15 & 277.1 \\
\hline
\end{tabular}

Figure 2 describes the coherence scores for different numbers of topics. Under the coherence test, as opposed to the perplexity validation test, a model with a higher coherence score before the sharp decline is identified as the best model. This test also indicates that a model with six topics would be an ideal model in our text corpus.

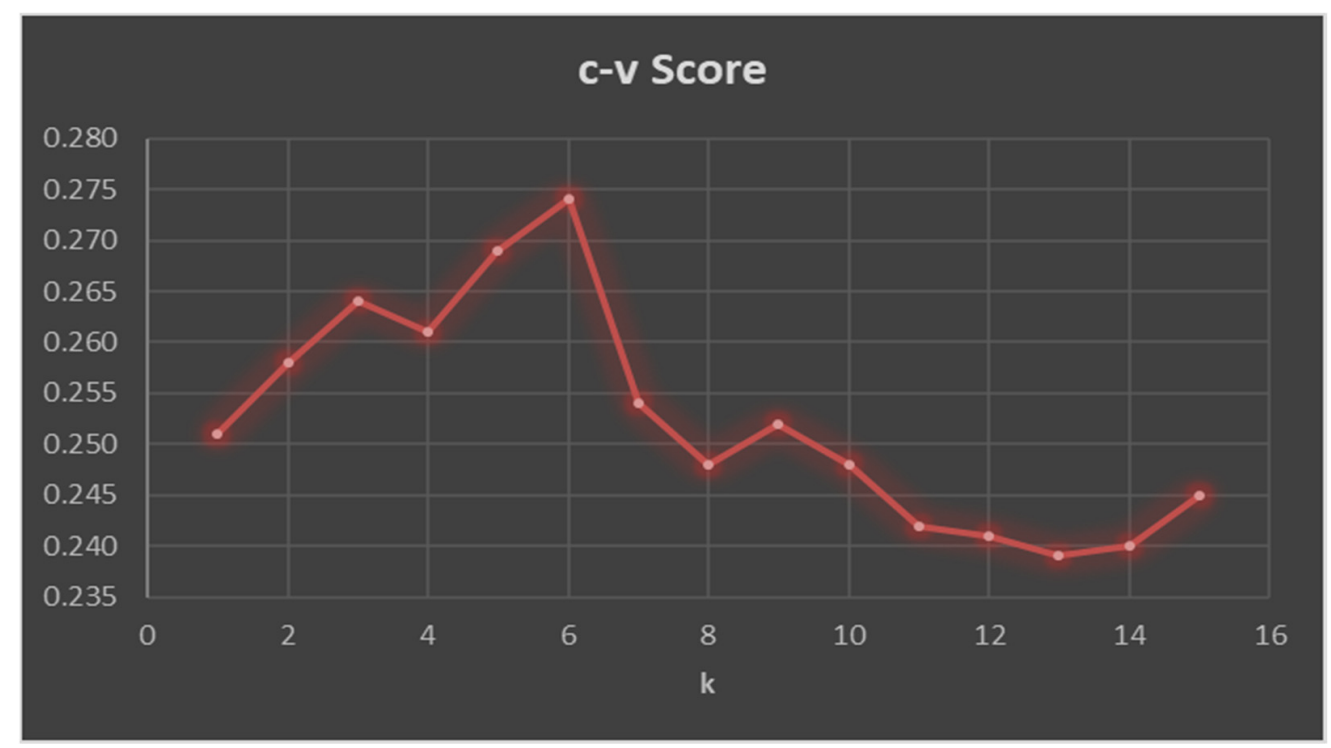

Figure 2. Coherence score.

Thus, based on model evaluation results, an LDA topic modeling algorithm was applied for six topics with seven terms/words and is displayed in Table 3. As a result of LDA, each topic contains several words. The quality of a topic model depends not only on its performance in statistical metrics but also on its reasonability and the interpretability of each topic [95]. LDA allows words to be present in multiple topics. For example, food appears in Topic 1 , Topic 2 , and Topic 3 . Similarly, consumption appears in Topic 1 , Topic 2 , 
and Topic 6. Results in Table 3 show that Topic 1 contains the words describing the organic foods, such as food, organic, local, and consumption. Thus, we name Topic 1 as Organic Food Consumption. Topic 2 consists of words describing food wastage with reference to the concern for climate change, such as food, product, and waste. So, we refer to Topic 2 as Food Waste. Topic 3 consists of the words vegan, food, ecological, and healthy, which describe vegan foods. Therefore, we name Topic 3 as Vegan Food. Topic 4 consists of the words describing tourism and sustainability, such as sustainable, tourism, responsible, and future. Thus, we refer to Topic 4 as Sustainable Tourism. Topic 5 discusses Sustainable Transport as it covers the words like transport, fuel, green, and energy. Topic 6 consists of words describing energy consumption, such as energy, consumption, bitcoin, green, and reduce. Therefore, we name Topic 6 Sustainable Energy Consumption.

Table 3. Topics with key terms.

\begin{tabular}{|c|c|c|}
\hline Topic id & Terms & Label \\
\hline Topic 1 & $\begin{array}{l}\text { food, organic, local, consumption, } \\
\text { agriculture, healthy, product }\end{array}$ & Organic Food Consumption \\
\hline Topic 2 & $\begin{array}{l}\text { food, product, waste, consumption, } \\
\text { global, resource, responsible }\end{array}$ & Food Waste \\
\hline Topic 3 & $\begin{array}{l}\text { vegan, food, eat, healthy, ecological, } \\
\text { buy, delicious }\end{array}$ & Vegan Food \\
\hline Topic 4 & $\begin{array}{l}\text { sustainable, tourism, join, world, } \\
\text { responsible, future, resource }\end{array}$ & Sustainable Tourism \\
\hline Topic 5 & $\begin{array}{l}\text { transport, fuel, climate, green, } \\
\text { energy, public, emission }\end{array}$ & Sustainable Transport \\
\hline Topic 6 & $\begin{array}{l}\text { energy, consumption, bitcoin, green, } \\
\text { reduce, industry, consumer }\end{array}$ & $\begin{array}{l}\text { Sustainable Energy } \\
\text { Consumption }\end{array}$ \\
\hline
\end{tabular}

LDAvis provides the visualization of topic distribution. Our LDAvis visualization result shows semantical distinct topics, which is an indication of the quality of topics (see Figure 3). The distance between bubbles (topics) shows semantic similarity (or dissimilarity). Topic 1 and Topic 2 slightly overlap as Topic 1, which is about organic food consumption, has a similar discussion frequency (keywords) with Topic 2 . Topic 1 , Topic 2 , and Topic 3 are close to each other as these topics are in connection with food. The size of the bubble shows the prominence of the topic based on the frequencies of relevant words. As per Figure 3, Topic 1 and Topic 2 are the most prominent topics, followed by Topic 3 .

\subsection{Semantic Analysis}

Visone software was used to visualize semantic networks. The semantic network contains 46 nodes (most frequent words from our corpus) and 186 edges (Figure 4). As per results, the central word consumption is connected with energy, environmental, lifestyle, electricity, responsible, reduce, data, and fashion, etc. while the other central term, sustainable, has associations with words such as carbon, energy, food, mining, bitcoin, blockchain, aviation, fuel, capitalism, etc. 
Intertopic Distance Map (via multidimensional scaling)

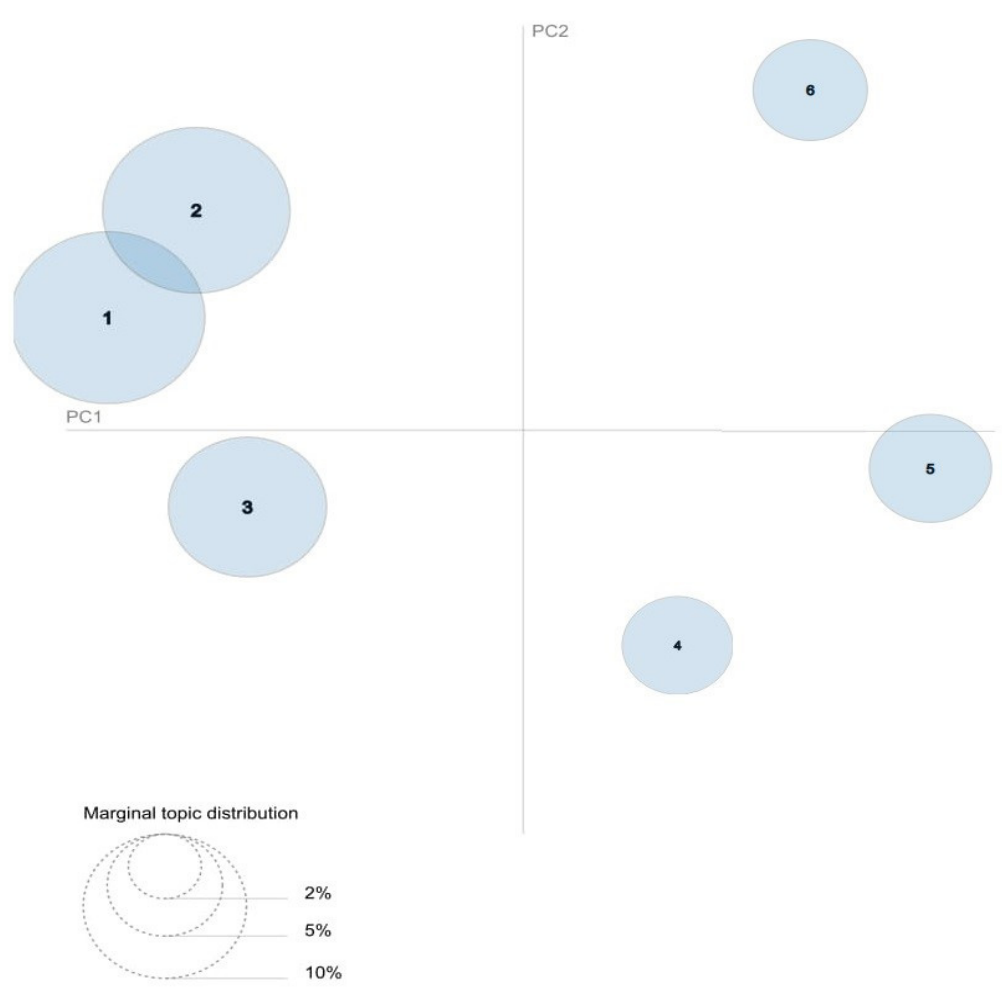

Figure 3. Visualization for topic distribution.

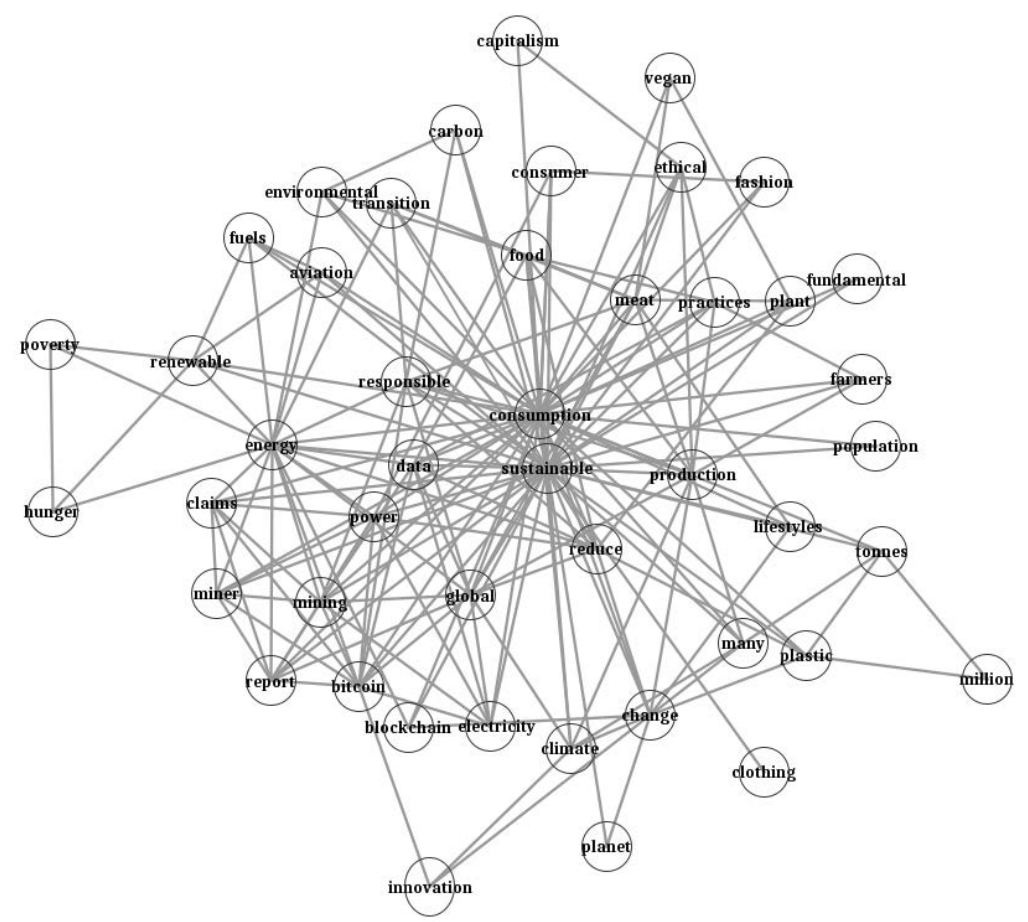

Figure 4. Semantic network analysis.

As the objective of the study is to identify the themes/topics related to sustainable consumption, the Louvain algorithm was also implemented to identify semantic clusters of latent topics. Results in Figure 5 show the presence of four distinct clusters with two sub-clusters within. The four broad clusters give us a different perspective on sustainable consumption. The first large cluster is related to lifestyle and climate change. The second 
big cluster is about responsible consumption. The next cluster talks about energy consumption on high computations for recent technologies like bitcoin and blockchain. The last one discusses the application of renewable energy for the sectors like aviation.

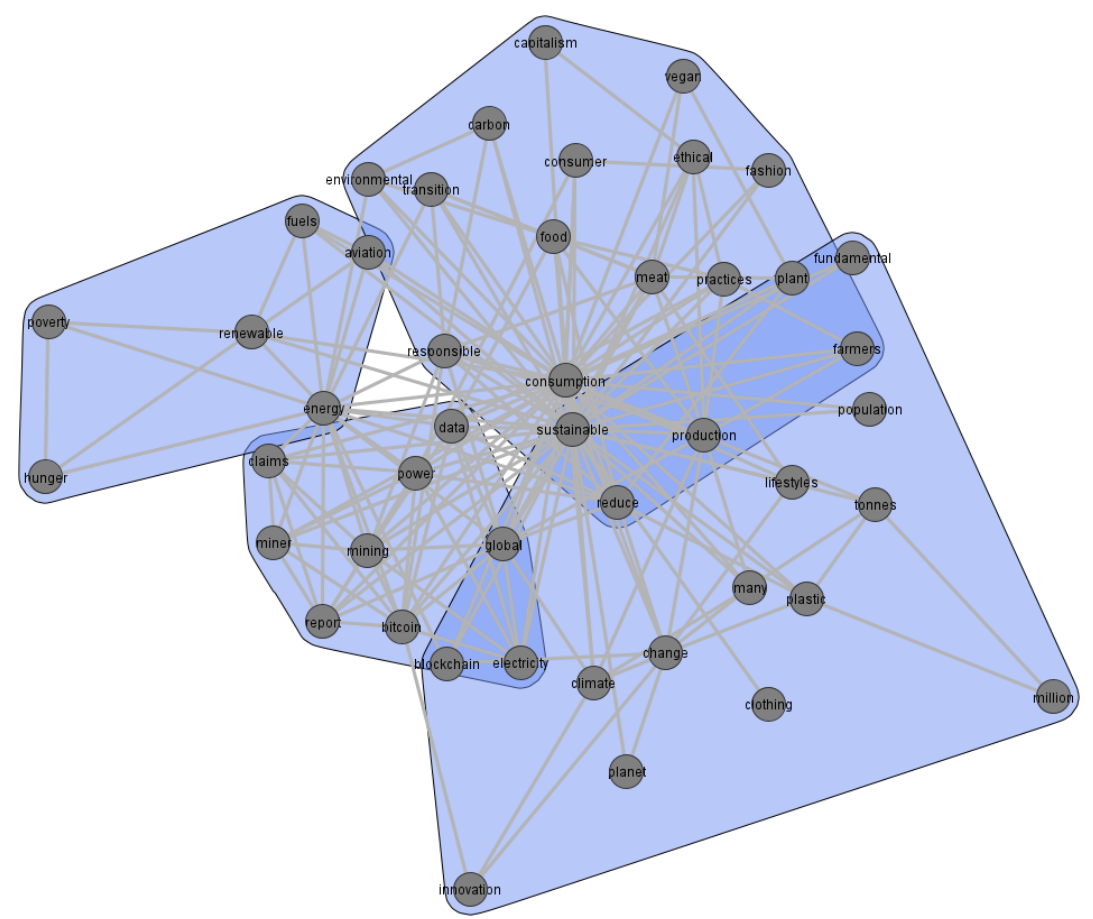

Figure 5. Semantic network analysis (with clusters).

\subsection{Sentiment Analysis}

We used the "syuzhet" package for sentiment analysis. We load the text data (tweets), split each word to form a character vector, and use the function get_nrc_sentiment() from the "syuzhet" library. This function takes words and compares them with the NRC emotion lexicon to return the score. As per our sentiment results (Figure 6), people have mixed sentiments (i.e., positive and negative) on sustainable consumption. However, positivity is prominent in our results due to the presence of high positive emotions (anticipation, joy, and trust). Some words having positive sentiments are abundance, healthy, opportunity, mindful, delicious, confident, prefer, recovery, protect, etc. Similarly, some words having negative sentiments are toxic, junk, waste, degradable, irresponsible, guilty, loss, etc.

Sentiment Score

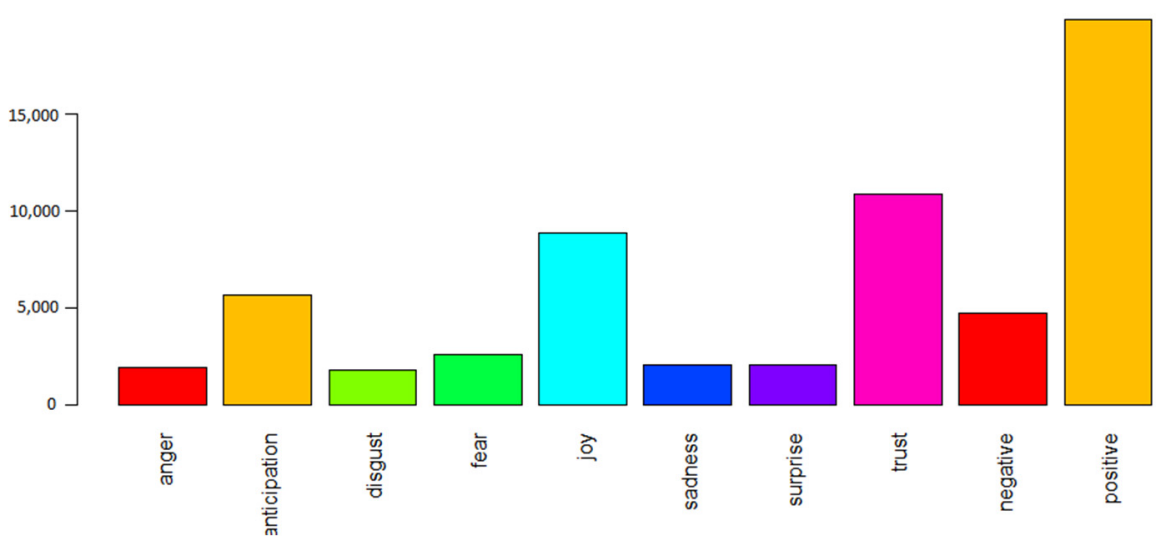

Figure 6. Public sentiment towards sustainable consumption. 


\section{Discussion}

Based on the LDA algorithm, we identified six main topics from the area of sustainable consumption that are of importance to Twitter users during COVID-19. The first topic emerging from the analysis concerns organic food consumption, i.e., food that is produced through environmentally friendly agricultural methods, without fertilizers and synthetic chemicals [96]. This result is not surprising given that the concern for health, including healthy eating, is gaining importance among consumers during the COVID-19 pandemic $[18,24]$. It is confirmed that if consumers are health-conscious, organic food is their first choice [97-99]. What is more, in the time of coronavirus, health consciousness is the most relevant driver that boosts the positive attitude towards organic food $[97,100]$. It can be assumed that the second topic, i.e., food waste, has become the focus of consumers' attention both due to the growing environmental and health consciousness of consumers, as well as some concerns about the economic crisis along with higher food prices caused by the COVID-19 pandemic [101]. These assumptions are confirmed, e.g., by the results of the study conducted in Italy, indicating that the amount of household food waste dropped during the coronavirus lockdown despite a rise in the amount of food purchased [102]. This may suggest that consumers are becoming more conscious of the necessity to reduce food waste during the pandemic for economic and environmental reasons [102,103]. Another topic, i.e., vegan food, is also related to food consumption. A vegan diet is rapidly gaining consumer acceptance [104]. Interest in this topic during the COVID-19 pandemic may be due to the results of some studies suggesting that a plant-based diet may help reduce the risk of severe COVID-19 [105,106]. Such diet results, among others, in lower obesity rates, diabetes, and dysbiosis, which could lead to lower and less serious infections, including COVID-19 disease [106]. The fourth topic is related to sustainable tourism, i.e., tourism that takes into consideration its present and future economic, social, and environmental impacts [107]. The COVID-19 pandemic has significantly affected the tourism industry [108-112]. Domestic and international traffic restrictions considerably influenced the growth of tourism demand [110]. On the one hand, the COVID-19 pandemic heavily hit the tourism industry, but on the other hand, the pandemic crisis led to the development of domestic and local tourism or electronic tourism (e-tourism), reducing emissions caused by decreasing travel $[108,109,112]$. Thus, the outbreak of the COVID-19 pandemic can also be considered a chance to make tourism more sustainable [113]. Taking into account the restrictions on mobility in the time of COVID-19, and growing interest in sustainable tourism [111], it is not surprising that many Twitter users have taken an interest in this topic during the COVID-19 pandemic. The fifth topic is related to sustainable transport, which is about moving in a way that not only meets the need for mobility, but is also safe, fast, accessible, and environmentally friendly [114]. The issue of sustainable transport during COVID-19 has been the subject of various research studies [115-117], proving its particular relevance during the pandemic. The restrictions related to mobility and the need for social distancing during the coronavirus pandemic resulted in lower demand for transport, reducing its negative environmental impact at the same time [118]. However, in a post-pandemic situation, the negative impact of transport can be even greater due to the possibility of avoiding public transport, where passengers are more likely to be infected with coronavirus, in favor of individual mobility solutions [119]. For this reason, sustainable transport challenges mainly relate to the post-COVID-19 period and include, above all, developing more responsible solutions required to transform mobility habits and decarbonize transport [116]. The sixth topic concerns sustainable energy consumption. Sustainable energy can be defined as a form of energy that is produced and used with regard to social and environmental requirements [120]. Taking into consideration the growing demand for energy around the world and the fact that energy production and consumption accounts for over two-thirds of global greenhouse gas emissions [121,122], in the time when the consequences of climate change are becoming more common [123], the topic of sustainable energy is extremely timely for discussion. It is worth noting the existence of a feedback loop between energy consumption and climate change. Just as increasing 
energy consumption influences climate change, increasingly noticeable weather changes (as a consequence of climate change) lead to a rapid increase in the use of air conditioning (on hot days) and heat pumps (on cold days), which is becoming one of the main factors in increasing demand for energy [124]. New challenges in the field of sustainable energy consumption have emerged with the outbreak of the coronavirus pandemic. Various studies confirm a serious drop in energy demand due to the pandemic [125-127]. While the decline in conventional energy consumption is positive from a sustainability perspective, COVID-19 has also led to a reduction in investment in renewable energy sources [126]. This state of affairs may also continue after the COVID-19 pandemic, as many countries see solutions to their economies hit by a pandemic recession by investing in industries that are not environmentally friendly [128]. It is also confirmed that during the COVID-19 pandemic, energy consumption strategies also shifted to more sustainable ones, especially in lower-income households where certain saving strategies were applied [129].

On the grounds of the Louvain algorithm, we identified the four semantic clusters of latent topics on sustainable consumption. The first large cluster is related to lifestyle and climate change. This cluster was discussed in the context of the COVID-19 in many previous papers from different points of view. For example, [130] investigated the impact of coronavirus isolation on lifestyle behaviors in Spanish children, while [131] investigated how COVID-19 reshaped lifestyles across societies. Similarly, various researchers are trying to explore the relationship between COVID-19 and climate change [132-134]. The second cluster is about responsible consumption. This notion is used interchangeably with the concept of sustainable consumption [23]. In the growing number of publications, sustainable consumption is examined from the COVID-19 perspective [19-23]. The next cluster considers energy consumption on high computations for recent technologies like bitcoin and blockchain. The link between blockchain and energy is not surprising because, as various studies confirm, the cryptocurrency bitcoin, which is based on blockchain technology, consumes an enormous amount of energy $[135,136]$. As previously noted, energy consumption in the context of COVID-19 has been the theme of a vast number of studies [125-127]. The last cluster is related to the application of renewable energy for the sectors like "aviation". For a long time, aviation has faced the challenges of decreasing the negative effect of aircraft on the ecosystem and energy consumption [137,138]. The researchers' interest in aviation also stems from the fact that the outbreak of the coronavirus pandemic has largely affected both the supply and demand chain for the aviation market [139]. The transition to sustainable aviation fuel can be an important element in the recovery of the aviation industry after the COVID-19 pandemic [140].

Taking into account the results of the sentiment analysis, it can be concluded that people have mixed sentiments (i.e., positive and negative) about sustainable consumption. A significant body of research shows that emotions play a crucial role in consumer behavior, including behavioral consumption patterns [141-144]. Research has also been carried out on the specific emotions (e.g., fear, guilt, joy, and pride) that shape sustainable consumption $[31,145,146]$, including the impact of emotions on sustainable consumption in the time of the COVID-19 pandemic $[21,147,148]$. In the above-mentioned publications, both the influence of the positive emotions, like sympathy, joy, and peacefulness [147], and negative emotions, e.g., consumers' perceived threat [21] on sustainable consumption during the COVID-19 pandemic, were analyzed.

\section{Conclusions}

This paper analyzed recent tweets on sustainable consumption posted on Twitter. The main strength of this study lies in its novel findings, obtained through advanced textmining approaches, such as LDA for topic modeling and Louvain Algorithm for semantic network analysis. One of the contributions of this work is the use of social media data as opposed to the conventional method of obtaining data from interviews and questionnairebased surveys. Every day millions of tweets are posted on Twitter that contain unbiased and rich opinions. Therefore, Twitter is an excellent source of data for researchers to help 
better understand public behaviors, opinions, and sentiments. Interviews often pose a bias/subjectivity as the interviewer's preconceived response or idea or opinion could affect the responses from the interviewees, while people freely express their unbiased views on social media platforms like Twitter.

This article contributes to the theory in the field of sustainable consumption by providing a fresh perspective on different interconnected sustainable consumption aspects that bring global consumption to a sustainable level. Specifically, it contributes to better understanding which topics of sustainable consumption are of importance to consumers during the COVID-19 pandemic. By applying big data and a number of text mining techniques, the present study implicates new opportunities for investigating issues related to sustainable consumption that would not be identifiable using other methods. The text mining techniques (such as LDA and semantic analysis) are emerging tools and have been recently used by researchers in behavioral sciences, but not in the context of sustainable consumption. In this sense, the present study contributes to existing knowledge of sustainable consumption using advanced computational methods. In particular, topic modeling was applied to discover latent topics, a semantic network was analyzed to describe semantic relations between concepts, and sentiment analysis was applied to extract sentiment on sustainable consumption. Apart from theoretical contribution, this research has industry and managerial implications. Most of all, managers and marketers of the restaurants \& food service industry can attract public/customers' attention positively through their strategic marketing communications on their food waste minimization and handling practices. Similarly, companies in the tourism industry can incorporate sustainability into their services and enjoy the benefits from the communications of their sustainability practices. Moreover, the considerations in this article, especially regarding the consumption of sustainable energy, may be useful for governments in creating an improved energy policy as well as for the energy sector, in facing the challenge of a sustainable transformation. In the field of government policy, this knowledge may serve as an inspiration for the transition of the current model of energy based on fossil fuels to a low-carbon energy system, and in the energy sector, for investment decisions for a sustainable transformation.

Despite the significant contributions, the study has some limitations. First, the data collection period was short. Second, this study drew only on Twitter as the social media data source. Thus, it might not be possible to generalize the findings to other social media platforms. Therefore, future studies may collect data from other social media platforms to validate the findings of this paper. Third, the present study used the streaming API method for data collection, which can retrieve tweets from the past 7 days. Further studies can use other methods to extract historical Twitter data to perform a temporal study to explore a broader view of sustainable consumption topics. Also, in future research, we recommend researchers focus on specific countries or continents to analyze what areas of sustainable consumption are essential to that country or continent. Fourth, the topics were labeled based on the authors' interpretations of the key terms. Fifth, we used a lexicon-based approach for sentiment analysis, which may fail to identify some human expressions like sarcasm and irony.

Author Contributions: Conceptualization, P.B. and A.S.; methodology, P.B. and A.S.; formal analysis, A.S.; investigation, P.B. and A.S.; data curation, A.S.; writing-original draft preparation, P.B. and A.S.; writing-review and editing, P.B. and A.S.; visualization, P.B. and A.S.; supervision, P.B.; funding acquisition, P.B. Both authors have read and agreed to the published version of the manuscript.

Funding: This research was funded by National Science Centre, Poland, decision number 2020/37/B/ HS4/00988.

Institutional Review Board Statement: Not applicable.

Informed Consent Statement: Not applicable.

Data Availability Statement: The data presented in this study are available on request from the authors.

Conflicts of Interest: The authors declare no conflict of interest. 


\section{References}

1. World Health Organization. Overview. Available online: https:/ /COVID19.who.int/ (accessed on 29 July 2021).

2. World Health Organization. Impact of COVID-19 on People's Livelihoods, Their Health and Our Food Systems. Available online: https:/ / www.who.int/news/item/13-10-2020-impact-of-COVID-19-on-people $\backslash T 1 \backslash$ textquoterights-livelihoods-theirhealth-and-our-food-systems (accessed on 29 July 2021).

3. Borsellino, V.; Kaliji, S.A.; Schimmenti, E. COVID-19 drives consumer behaviour and agro-food markets towards healthier and more sustainable patterns. Sustainability 2020, 12, 8366. [CrossRef]

4. Pak, A.; Adegboye, O.A.; Adekunle, A.I.; Rahman, K.M.; McBryde, E.S.; Eisen, D.P. Economic consequences of the COVID-19 outbreak: The need for epidemic preparedness. Front. Public Health 2020, 8, 241. [CrossRef]

5. Vernengo, M.; Nabar-Bhaduri, S. The economic consequences of COVID-19: The great shutdown and the rethinking of economic policy. Int. J. Political Econ. 2020, 49, 265-277. [CrossRef]

6. Rasul, G.; Nepal, A.K.; Hussain, A.; Maharjan, A.; Joshi, S.; Lama, A.; Gurung, P.; Ahmad, F.; Mishra, A.; Sharma, E. Socioeconomic implications of COVID-19 pandemic in South Asia: Emerging risks and growing challenges. Front. Sociol. 2021, 6, 629693. [CrossRef] [PubMed]

7. Arzhanova, K.A.; Beregovskaya, T.A.; Silina, S.A. The impact of the COVID-19 pandemic on consumer behavior and companies' internet communication. Adv. Soc. Sci. Educ. Humanit. Res. 2020, 486, 50-57.

8. Martin, A.; Markhvida, M.; Hallegatte, S.; Walsh, B. Socio-Economic Impacts of COVID-19 on Household Consumption and Poverty. Econ. Dis. Clim. Chang. 2020, 4, 453-479. [CrossRef] [PubMed]

9. Hesham, F.; Riadh, H.; Sihem, N.K. What have we learned about the effects of the COVID-19 pandemic on consumer behavior? Sustainability 2021, 13, 4304. [CrossRef]

10. Verma, M.; Naveen, B.R. COVID-19 impact on buying behaviour. Vikalpa 2021, 46, 27-40. [CrossRef]

11. Cavallo, C.; Sacchi, G.; Carfora, V. Resilience effects in food consumption behaviour at the time of Covid-19: Perspectives from Italy. Heliyon 2020, 6, 1-8. [CrossRef]

12. Mehta, S.; Saxena, T.; Purohit, N. The new consumer behaviour paradigm amid COVID-19: Permanent or transient? J. Health Manag. 2020, 22, 291-301. [CrossRef]

13. Sheth, J. Impact of COVID-19 on consumer behavior: Will the old habits return or die? J. Bus. Res. 2020, 117, 280-283. [CrossRef] [PubMed]

14. Ahmed, R.R.; Streimikiene, D.; Rolle, J.-A.; Duc, P.A. The COVID-19 pandemic and the antecedants for the impulse buying behavior of US citizens. J. Compet. 2020, 12, 5-27. [CrossRef]

15. Sayyida, S.; Hartini, S.; Gunawan, S.; Husin, S.N. The impact of the COVID-19 pandemic on retail consumer behavior. APTISI Trans. Manag. ATM 2021, 5, 79-88.

16. Trzebiński, W.; Baran, R.; Marciniak, B. Did the COVID-19 pandemic make consumers shop alone? The role of emotions and interdependent self-construal. Sustainability 2021, 13, 6361. [CrossRef]

17. Zwanka, R.J.; Buff, C. COVID-19 generation: A conceptual framework of the consumer behavioral shifts to be caused by the COVID-19 pandemic. J. Int. Consum. Mark. 2021, 33, 58-67. [CrossRef]

18. Orîndaru, A.; Popescu, M.-F.; Caescu, S.-C.; Botezatu, F.; Florescu, M.S.; Runceanu-Albu, C.-C. Leveraging COVID-19 outbreak for shaping a more sustainable consumer behavior. Sustainability 2021, 13, 5762. [CrossRef]

19. Cohen, M.J. Does the COVID-19 outbreak mark the onset of a sustainable consumption transition? Sustain. Sci. Pract. Policy 2020, 16, 1-3. [CrossRef]

20. Ali, Q.; Parveen, S.; Yaacob, H.; Zaini, Z.; Sarbini, N.A. COVID-19 and dynamics of environmental awareness, sustainable consumption and social responsibility in Malaysia. Environ. Sci. Pollut. Res. Int. 2021, 28, 1-20.

21. Chae, M.-J. Effects of the COVID-19 pandemic on sustainable consumption. Soc. Behav. Personal. 2021, 49, e10199. [CrossRef]

22. Giannetti, B.F.; Fonseca, T.; Almeida, C.M.V.B.; Oliveira, J.H.; Valenti, W.C.; Agostinho, F. Beyond a sustainable consumption behavior: What post-pandemic world do we want to live in? Front. Sustain. 2021, 2, 635761. [CrossRef]

23. Perkins, K.M.; Velazquez, L.; Munguia, N. Reflections on sustainable consumption in the context of COVID-19. Front. Sustain. 2021, 2, 647542. [CrossRef]

24. Naja, F.; Hamadeh, R. Nutrition amid the COVID-19 pandemic: A multi-level framework for action. Eur. J. Clin. Nutr. 2020, 74, 1117-1121. [CrossRef] [PubMed]

25. Severo, E.A.; De Guimarães, J.C.F.; Dellarmelin, M.L. Impact of the COVID-19 pandemic on environmental awareness, sustainable consumption and social responsibility: Evidence from generations in Brazil and Portugal. J. Clean. Prod. 2021, 286, 124947. [CrossRef]

26. Degli Esposti, P.; Mortara, A.; Roberti, G. Sharing and Sustainable Consumption in the Era of COVID-19. Sustainability 2021, 13, 1903. [CrossRef]

27. Martin, D.; Schouten, J. Sustainable Marketing, 1st ed.; Prentice Hall: Upper Saddle River, NJ, USA, $2012 ;$ pp. 1-247.

28. Hofacker, C.F.; Malthouse, E.C.; Sultan, F. Big Data and consumer behavior: Imminent opportunities. J. Consum. Mark. 2016, 33, 89-97. [CrossRef]

29. Kotler, P.; Keller, K.L.; Brady, M.; Goodman, M.; Hansen, T. Marketing Management, 4th ed.; Pearson Education: Harlow, UK, 2019; pp. 1-840. 
30. Joshi, Y.; Rahman, Z. Factors affecting green purchase behaviour and future research directions. Int. J. Manag. Rev. 2015, 3, 128-143. [CrossRef]

31. White, K.; Habib, R.; Hardisty, D.J. How to SHIFT consumer behaviors to be more sustainable: A literature review and guiding framework. J. Mark. 2019, 83, 22-49. [CrossRef]

32. Yue, B.; Sheng, G.; She, S.; Xu, J. Impact of consumer environmental responsibility on green consumption behavior in China: The role of environmental concern and price sensitivity. Sustainability 2020, 12, 2074. [CrossRef]

33. Chen, T.B.; Chai, L.T. Attitude towards the environment and green products: Consumers' perspective. Manag. Sci. Eng. 2010, 4, 27-39.

34. Karsaklian, E.; Fee, A. From Green to Ethical Consumers: What Really Motivates Consumers to Buy Ethical Products? In Looking Forward, Looking Back: Drawing on the Past to Shape the Future of Marketing; Campbell, C., Ma, J., Eds.; Springer: Cham, Germany, 2016; pp. 192-201.

35. Fraj, E.; Martinez, E. Ecological consumer behaviour: An empirical analysis. Int. J. Consum. Stud. 2006, 31, 26-33. [CrossRef]

36. Rueda, X.; Lambin, E.F. Linking globalization to local land uses: How eco-consumers and gourmands are changing the Colombian coffee landscapes. World Dev. 2013, 41, 286-301. [CrossRef]

37. Barbarossa, C.; Pastore, A. Why environmentally conscious consumers do not purchase green products: A cognitive mapping approach. Qual. Mark. Res. 2015, 18, 188-209. [CrossRef]

38. Finisterra do Paço, A.M.; Raposo, M.L.B. Green consumer market segmentation: Empirical findings from Portugal. Int. J. Consum. Stud. 2010, 34, 429-436. [CrossRef]

39. Yahya, W.K.; Musa, N.D.; Hashim, N.H. Understanding Environmentally Friendly Consumer Behavior. In Regional Conference on Science, Technology and Social Sciences (RCSTSS 2014); Abdullah, M., Yahya, W., Ramli, N., Mohamed, S., Ahmad, B., Eds.; Springer: Singapore, 2016; pp. 909-921.

40. Musová, Z.; Musa, H.; Ludhova, L. Environmentally responsible purchasing in Slovakia. Econ. Sociol. 2018, 11, 289-305. [CrossRef]

41. Wooliscroft, B.; Ganglmair-Wooliscroft, A.; Noone, A. The hierarchy of ethical consumption behavior: The case of New Zealand. J. Macromarke. 2014, 34, 57-72. [CrossRef]

42. Villa Castaño, L.E.; Perdomo-Ortiz, J.; Dueñas Ocampo, S.; Durán León, W.F. Socially responsible consumption: An application in Colombia. Bus. Ethics 2016, 25, 460-481. [CrossRef]

43. Belz, F.-M.; Peattie, K. Sustainability Marketing: A Global Perspective, 2nd ed.; John Wiley \& Sons: Chichester, UK, $2012 ;$ pp. 1-352.

44. Hüttel, A.; Ziesemer, F.; Peyer, M.; Balderjahn, I. To purchase or not? Why consumers make economically (non-)sustainable consumption choices. J. Clean. Prod. 2018, 174, 827-836. [CrossRef]

45. Ah Fook, L.; McNeill, L. Click to buy: The impact of retail credit on over-consumption in the online environment. Sustainability 2020, 12, 7322. [CrossRef]

46. Brzustewicz, P. Sustainable consumption as a new challenge for contemporary marketing. Mark. I Rynek 2015, 8, 70-78. (In Polish)

47. Nita, V.; Castellani, V.; Sala, S. Consumer's Behaviour in Assessing Environmental Impact of Consumption. In State of the Art and Challenges for Modelling Consumer's Behaviour in Life Cycle Based Indicators; Publications Office of the European Union: Luxembourg, 2017; pp. 1-58.

48. Gan, C.; Wee, H.Y.; Ozanne, L.; Kao, T.-H. Consumers' purchasing behavior towards green products in New Zealand. Innov. Mark. 2008, 4, 93-102.

49. Scott, K.A. Literature Review on Sustainable Lifestyles and Recommendations for Further Research; Stockholm Environment Institute: Stockholm, Sweden, 2009; pp. 1-34.

50. Joshi, Y.; Rahman, Z. Consumers' sustainable purchase behaviour: Modeling the impact of psychological factors. Ecol. Econ. 2019, 159, 235-243. [CrossRef]

51. Zhang, X.; Dong, F. Why do consumers make green purchase decisions? Insights from a systematic review. Int. J. Environ. Res. Public Health 2020, 17, 1-25.

52. Elhoushy, S.; Lanzini, P. Factors affecting sustainable consumer behavior in the MENA region: A systematic review. J. Int. Consum. Mark. 2021, 33, 256-279. [CrossRef]

53. Csikszentmihalyi, M. The Costs and Benefits of Consuming. J. Consum. Res. 2000, 27, 267-272. [CrossRef]

54. Kjellberg, H. Market practices and over-consumption. Consum. Mark. Cult. 2008, 11, 151-167. [CrossRef]

55. Roach, B.; Goodwin, N.; Nelson, J. Consumption and the Consumer Society; Global Development and Environment Institute, Tufts University: Medford, MA, USA, 2019; pp. 1-42.

56. Bengtsson, M.; Alfredsson, E.; Cohen, M.; Lorek, S.; Schroeder, P. Transforming systems of consumption and production for achieving the sustainable development goals: Moving beyond efficiency. Sustain. Sci. 2018, 13, 1533-1547. [CrossRef]

57. Mazurek-Łopacińska, K.; Sobocińska, M. Ecologisation of consumption as a trend in consumer behavior-implications for future research. Int. Bus. Glob. Econ. 2018, 37, 409-420. [CrossRef]

58. Bauer, B.; Watson, D.; Gylling, A.C. Sustainable Consumption and Production. An Analysis of Nordic Progress towards SDG12, and the Way Ahead; Nordic Council of Ministers: Copenhagen, Denmark, 2018; pp. 1-48.

59. UNEP. Sustainable Consumption and Production. A Handbook for Policymakers; UNEP: Nairobi, Kenya, $2015 ;$ pp. 1-213. 
60. United Nations. Transforming Our World: The 2030 Agenda for Sustainable Development. Available online: https://www.un. org/en/development/desa/population/migration/generalassembly/docs/globalcompact/A_RES_70_1_E.pdf (accessed on 19 July 2021).

61. United Nations. Goal 12: Ensure Sustainable Consumption and Production Patterns. Available online: https://www.un.org/ sustainabledevelopment/sustainable-consumption-production (accessed on 19 July 2021).

62. Jackson, T. Sustainable Consumption. In Handbook of Sustainable Development, 2nd ed.; Atkinson, G., Dietz, S., Neumayer, E., Agarwala, M., Eds.; Edwards Elgar: Cheltenham, UK, 2014; pp. 1-624.

63. Hertwich, E.G. Life cycle approaches to sustainable consumption: A critical review. Environ. Sci. Technol. 2005, 39, 4673-4684. [CrossRef]

64. United Nations. Paving the Way to Sustainable Consumption and Production. Marrakech Process Progress Report; UNEP: Nairobi, Kenya, 2011; pp. 1-104.

65. Benoit, S.; Baker, T.L.; Bolton, R.N.; Gruber, T.; Kandampully, J. A triadic framework for collaborative consumption (CC): Motives, activities and resources \& capabilities of actors. J. Bus. Res. 2017, 79, 219-227.

66. Luri Minami, A.; Ramos, C.; Bruscato Bortoluzzo, A. Sharing economy versus collaborative consumption: What drives consumers in the new forms of exchange? J. Bus. Res. 2021, 128, 124-137. [CrossRef]

67. Padilla, E. Factors Leading to Sustainable Consumption (and Barriers to It); UNIDO: Vienna, Austria, 2018; pp. 1-43.

68. Tomșa, M.-M.; Romonți-Maniu, A.-I.; Scridon, M.-A. Is sustainable consumption translated into ethical consumer behavior? Sustainability 2021, 13, 3466. [CrossRef]

69. Huang, X.; Lin, Y.; Zhou, F.; Lim, M.K.; Chen, S. Agent-based modelling for market acceptance of electric vehicles: Evidence from China. Sustain. Prod. Consum. 2021, 28, 206-217. [CrossRef]

70. Chen, X.; Shuai, C.; Wu, Y.; Zhang, Y. Understanding the sustainable consumption of energy resources in global industrial sector: Evidences from 114 countries. Environ. Impact Assess. Rev. 2021, 90, 106609. [CrossRef]

71. Zucchinelli, M.; Spinelli, R.; Corrado, S.; Lamastra, L. Evaluation of the influence on water consumption and water scarcity of different healthy diet scenarios. J. Environ. Manag. 2021, 291, 112687. [CrossRef]

72. Li, G.; Han, X.; Luo, Q.; Zhu, W.; Zhao, J. A study on the relationship between income change and the water footprint of food consumption in urban China. Sustainability 2021, 13, 7076. [CrossRef]

73. Coderoni, S.; Perito, M.A. Approaches for reducing wastes in the agricultural sector. An analysis of Millennials' willingness to buy food with upcycled ingredients. Waste Manag. 2021, 126, 283-290. [CrossRef]

74. Kumar, S.; Yadav, R. The impact of shopping motivation on sustainable consumption: A study in the context of green apparel. $J$. Clean. Prod. 2021, 295, 126239. [CrossRef]

75. Louis, D.; Lombart, C.; Durif, F. Packaging-free products: A lever of proximity and loyalty between consumers and grocery stores. J. Retail. Consum. Serv. 2021, 60, 102499. [CrossRef]

76. Wang, J.; Yu, X. The driving path of customer sustainable consumption behaviors in the context of the sharing economy-based on the interaction effect of customer signal, service provider signal, and platform signal. Sustainability 2021, 13, 3826. [CrossRef]

77. Sharpley, R. On the need for sustainable tourism consumption. Tour. Stud. 2021, 21, 96-107. [CrossRef]

78. Cohen, M.J. New Conceptions of Sufficient Home Size in High-Income Countries: Are We Approaching a Sustainable Consumption Transition? Hous. Theory Soc. 2021, 38, 173-203. [CrossRef]

79. Siddiqui, A.; Pandit, R.K. Smart Cities in India: Linkages with Circular Economy. In Sustainability in the Built Environment in the 21st Century: Lessons Learned from India and the Region; Iyer-Raniga, U., Ed.; Springer: Cham, Germany, 2021; pp. 185-200.

80. Bocken, N.M.P.; Short, S.W.; Rana, P.; Evans, S. A literature and practice review to develop sustainable business model archetypes. J. Clean. Prod. 2014, 65, 42-56. [CrossRef]

81. Vermeir, I.; Verbeke, W. Sustainable food consumption: Exploring the consumer "attitude—Behavioral intention" gap. J. Agric. Environ. Ethics 2006, 19, 169-194. [CrossRef]

82. Hoekstra, A.Y.; Mekonnen, M.M. The water footprint of humanity. Proc. Natl. Acad. Sci. USA 2012, 109, 3232-3237. [CrossRef]

83. Young, W.; Hwang, K.; McDonald, S.; Oates, C.J. Sustainable consumption: Green consumer behaviour when purchasing products. Sustain. Dev. 2010, 18, 20-31. [CrossRef]

84. Tukker, A.; Tischner, U. Product-services as a research field: Past, present and future. Reflections from a decade of research. J. Clean. Prod. 2006, 14, 1552-1556. [CrossRef]

85. Mekonnen, M.M.; Hoekstra, A.Y. A Global Assessment of the Water Footprint of Farm Animal Products. Ecosystems 2012, 15, 401-415. [CrossRef]

86. Papargyropoulou, E.; Lozano, R.; Steinberger, J.K.; Wright, N.; Ujang, Z.B. The food waste hierarchy as a framework for the management of food surplus and food waste. J. Clean. Prod. 2014, 76, 106-115. [CrossRef]

87. Tanner, C.; Kast, S.W. Promoting Sustainable Consumption: Determinants of Green Purchases by Swiss Consumers. Psychol. Mark. 2003, 20, 883-902. [CrossRef]

88. Vermeir, I.; Verbeke, W. Sustainable food consumption among young adults in Belgium: Theory of planned behaviour and the role of confidence and values. Ecol. Econ. 2008, 64, 542-553. [CrossRef]

89. Hargreaves, T. Practice-ing behaviour change: Applying social practice theory to pro-environmental behaviour change. J. Consum. Cult. 2011, 11, 79-99. [CrossRef] 
90. Antonakaki, D.; Fragopoulou, P.; Ioannidis, S. A survey of Twitter research: Data model, graph structure, sentiment analysis and attacks. Expert Syst. Appl. 2021, 164, 114006. [CrossRef]

91. Blei, D.M.; Ng, A.Y.; Jordan, M.I. Latent Dirichlet Allocation. J. Mach. Learn. Res. 2003, 3, 993-1022.

92. Ramage, D.; Dumais, S.; Liebling, D. Characterizing microblogs with topic models. In Proceedings of the International AAAI Conference on Web and Social Media, Washington, DC, USA, 23-26 May 2010; Volume 4, pp. 130-137.

93. Koylu, C.; Larson, R.; Dietrich, B.J.; Lee, K.-P. CarSenToGram: Geovisual text analytics for exploring spatiotemporal variation in public discourse on Twitter. Cart. Geogr. Inf. Sci. 2018, 46, 57-71. [CrossRef]

94. Feizollah, A.; Mostafa, M.M.; Sulaiman, A.; Zakaria, Z.; Firdaus, A. Exploring halal tourism tweets on social media. J. Big Data 2021, 8, 1-18. [CrossRef]

95. Heng, Y.; Gao, Z.; Jiang, Y.; Chen, X. Exploring hidden factors behind online food shopping from Amazon reviews: A topic mining approach. J. Retail. Consum. Serv. 2018, 42, 161-168. [CrossRef]

96. Cachero-Martínez, S. Consumer behaviour towards organic products: The moderating role of environmental concern. J. Risk Financ. Manag. 2020, 13, 330. [CrossRef]

97. Chaturvedi, A.; Rashid Chand, M.; Rahman, M. Impact of the COVID-19 on consumer behavior towards organic food in India. In Predictive and Preventive Measures for COVID-19 Pandemic. Algorithms for Intelligent Systems; Khosla, P.K., Mittal, M., Sharma, D., Goyal, L.M., Eds.; Springer: Singapore, 2021; pp. 127-148.

98. Nagaraj, S. Role of consumer health consciousness, food safety \& attitude on organic food purchase in emerging market: A serial mediation model. J. Retail. Consum. Serv. 2021, 59, 102423.

99. Iqbal, J.; Yu, D.; Zubair, M.; Rasheed, M.I.; Khizar, H.M.U.; Imran, M. Health consciousness, food safety concern, and consumer purchase intentions toward organic food: The role of consumer involvement and ecological motives. SAGE Open 2021, 11, 1-14. [CrossRef]

100. Castellini, G.; Savarese, M.; Graffigna, G. The impact of COVID-19 outbreak in Italy on the sustainable food consumption intention from a "one health" perspective. Front. Nutr. 2021, 8, 622122. [CrossRef]

101. Roe, B.E.; Bender, K.; Qi, D. The impact of COVID-19 on consumer food waste. Appl. Econ. Perspect. Policy 2021, $43,401-411$. [CrossRef]

102. Pappalardo, G.; Cerroni, S.; Nayga, R.M., Jr.; Yang, W. Impact of COVID-19 on household food waste: The case of Italy. Front. Nutr. 2020, 7, 585090. [CrossRef]

103. Amicarelli, V.; Bux, C. Food waste in Italian households during the COVID-19 pandemic: A self-reporting approach. Food Sec. 2021, 13, 25-37. [CrossRef]

104. Radnitz, C.; Ni, J.; Dennis, D.; Cerrito, B. Health benefits of a vegan diet: Current insights. Nutr. Diet. Suppl. 2020, 12, 57-85. [CrossRef]

105. Kim, H.; Rebholz, C.M.; Hegde, S.; LaFiura, C.; Raghavan, M.; Lloyd, J.F.; Cheng, S.; Seidelmann, S.B. Plant-based diets, pescatarian diets and COVID-19 severity: A population-based case-control study in six countries. BMJ Nutr. Prev. Health 2021, 4, 257-266. [CrossRef]

106. Losso, J.N.; Losso, M.N.; Toc, M.; Inungu, J.N.; Finley, J.W. The young age and plant-based diet hypothesis for low SARS-CoV-2 infection and COVID-19 pandemic in Sub-Saharan Africa. Plant. Foods Hum. Nutr. 2021, 76, 270-280. [CrossRef]

107. Available online: https://sustainabledevelopment.un.org/topics/sustainabletourism (accessed on 4 August 2021).

108. Gretzel, U.; Fuchs, M.; Baggio, R.; Hoepken, W.; Law, R.; Neidhardt, J.; Pesonen, J.; Zanker, M.; Xiang, Z. e-Tourism beyond COVID-19: A call for transformative research. Inf. Technol. Tour. 2020, 22, 187-203. [CrossRef]

109. Abbas, J.; Mubeen, R.; Iorember, P.T.; Raza, S.; Mamirkulova, G. Exploring the impact of COVID-19 on tourism: Transformational potential and implications for a sustainable recovery of the travel and leisure industry. Curr. Res. Behav. Sci. 2021, 2, 100033. [CrossRef]

110. Varzaru, A.A.; Bocean, C.G.; Cazacu, M. Rethinking tourism industry in pandemic COVID-19 period. Sustainability 2021, $13,6956$. [CrossRef]

111. Palacios-Florencio, B.; Santos-Roldán, L.; Berbel-Pineda, J.M.; Castillo-Canalejo, A.M. Sustainable tourism as a driving force of the tourism industry in a post-COVID-19 scenario. Soc. Indic. Res. 2021, 1-21. [CrossRef]

112. Arbulú, I.; Razumova, M.; Rey-Maquieira, J.; Sastre, F. Can domestic tourism relieve the COVID-19 tourist industry crisis? The case of Spain. J. Dest. Mark. Manag. 2021, 20, 100568.

113. Romagosa, F. The COVID-19 crisis: Opportunities for sustainable and proximity tourism. Tour. Geogr. 2020, 22, 690-694. [CrossRef]

114. Brzustewicz, P. Sustainable solutions for urban transport—directions of development. Acta Univ. Nicolai Copernic. 2013, 413, 85-96. (In Polish)

115. Koehl, A. Urban transport and COVID-19: Challenges and prospects in low- and middle-income countries. Cities Health 2020, 1-7. [CrossRef]

116. Budd, L.; Ison, S. Responsible transport: A post-COVID agenda for transport policy and practice. Transp. Res. Interdiscip. Perspect. 2020, 6, 100151.

117. Griffiths, S.; Furszyfer Del Rio, D.; Sovacool, B. Policy mixes to achieve sustainable mobility after the COVID-19 crisis. Renew. Sustain. Energy Rev. 2021, 143, 110919. [CrossRef] 
118. Du, J.; Rakha, H.A.; Filali, F.; Eldardiry, H. COVID-19 pandemic impacts on traffic system delay, fuel consumption and emissions. Int. J. Transp. Sci. Technol. 2021, 10, 184-196. [CrossRef]

119. Christidis, P.; Christodoulou, A.; Navajas-Cawood, E.; Ciuffo, B. The post-pandemic recovery of transport activity: Emerging mobility patterns and repercussions on future evolution. Sustainability 2021, 13, 6359. [CrossRef]

120. Rosen, M.A. Energy sustainability with a focus on environmental perspectives. Earth Syst. Environ. 2021, 5, 217-230. [CrossRef]

121. ÓhAiseadha, C.; Quinn, G.; Connolly, R.; Connolly, M.; Soon, W. Energy and climate policy-An evaluation of global climate change expenditure 2011-2018. Energies 2020, 13, 4839. [CrossRef]

122. European Environment Agency. Energy and Climate Change. Available online: https://www.eea.europa.eu/signals/signals-20 17 /articles/energy-and-climate-change (accessed on 4 August 2021).

123. Ornes, S. How does climate change influence extreme weather? Impact attribution research seeks answers. Proc. Natl. Acad. Sci. USA 2018, 115, 1-4. [CrossRef] [PubMed]

124. Li, Y.; Pizer, W.A.; Wu, L. Climate change and residential electricity consumption in the Yangtze River Delta, China. Proc. Natl. Acad. Sci. USA 2019, 116, 472-477. [CrossRef] [PubMed]

125. Mulvaney, D.; Busby, J.; Bazilian, M.D. Pandemic disruptions in energy and the environment. Elem. Sci. Anth. 2020, 8, 1-13. [CrossRef]

126. Eroğlu, H. Effects of COVID-19 outbreak on environment and renewable energy sector. Environ. Dev. Sustain. 2021, 23, 4782-4790. [CrossRef] [PubMed]

127. Xu, A.T.; Gao, B.W.; Li, C.Y.; Qian, D.F. Impact of the COVID-19 pandemic on the reduction of electricity demand and the integration of renewable energy into the power grid. J. Renew. Sustain. Energy 2021, 13, 026304.

128. Rita, E.; Chizoo, E.; Cyril, U.S. Sustaining COVID-19 pandemic lockdown era air pollution impact through utilization of more renewable energy resources. Heliyon 2021, 7, 1-14. [CrossRef]

129. Cuerdo-Vilches, T.; Navas-Martín, M.Á.; Oteiza, I. Behavior patterns, energy consumption and comfort during COVID-19 lockdown related to home features, socioeconomic factors and energy poverty in Madrid. Sustainability 2021, 13, 5949. [CrossRef]

130. Medrano, M.; Cadenas-Sanchez, C.; Oses, M.; Arenaza, L.; Amasene, M.; Labayen, I. Changes in lifestyle behaviours during the COVID-19 confinement in Spanish children: A longitudinal analysis from the MUGI project. Pediatric Obes. 2021, 6, e12731.

131. Echegaray, F.; Brachya, V.; Vergragt, P.J.; Zhang, L. Sustainable Lifestyles after COVID-19, 1st ed.; Routledge: London, UK, 2021; pp. $1-150$.

132. Usman, M.; Husnain, M.; Riaz, A.; Ali, Y. Climate change during the COVID-19 outbreak: Scoping future perspectives. Environ. Sci. Pollut. Res. 2021, 28, 49302-49313. [CrossRef]

133. Robertson, R. Humanity for itself? Reflections on climate change and the COVID-19 pandemic. Globalizations 2021, 18, 762-770. [CrossRef]

134. Samani, P.; García-Velásquez, C.; Fleury, P.; Van der Meer, Y. The Impact of the COVID-19 outbreak on climate change and air quality: Four country case studies. Glob. Sustain. 2021, 4, E9. [CrossRef]

135. de Vries, A. Bitcoin's growing energy problem. Joule 2018, 2, 801-805. [CrossRef]

136. Sedlmeir, J.; Buhl, H.U.; Fridgen, G. The energy consumption of blockchain technology: Beyond myth. Bus. Inf. Syst. Eng. 2020, 62, 599-608. [CrossRef]

137. Hari, T.; Yaakob, Z.; Binitha, N.N. Aviation biofuel from renewable resources: Routes, opportunities and challenges. Renew. Sustain. Energy Rev. 2015, 42, 1234-1244. [CrossRef]

138. Warimani, M.; Azami, M.H.; Savill, M.; Li, Y.-G.; Khan, S.A.; Ismail, A.F. Investigation of aircraft engine performance utilizing various alternative fuels. IOP Conf. Ser. Mater. Sci. Eng. 2019, 642, 012008. [CrossRef]

139. Dube, K.; Nhamo, G.; Chikodzi, D. COVID-19 pandemic and prospects for recovery of the global aviation industry. J. Air Transp. Manag. 2021, 92, 102022. [CrossRef]

140. Gössling, S.; Humpe, A.; Fichert, F.; Creutzig, F. COVID-19 and pathways to low-carbon air transport until 2050. Environ. Res. Lett. 2021, 16, 034063. [CrossRef]

141. Laros, F.J.M.; Steenkamp, J.-B.E.M. Emotions in consumer behavior: A hierarchical approach. J. Bus. Res. 2005, 58, 1437-1445. [CrossRef]

142. Watson, L.; Spence, M.T. Causes and consequences of emotions on consumer behaviour: A review and integrative cognitive appraisal theory. Eur. J. Mark. 2007, 41, 487-511. [CrossRef]

143. de Hooge, I. Predicting consumer behavior with two emotion appraisal dimensions: Emotion valence and agency in gift giving. Int. J. Res. Mark. 2014, 31, 380-394. [CrossRef]

144. Bettiga, D.; Lamberti, L. Future-oriented happiness: Its nature and role in consumer decision-making for new products. Front. Psychol. 2020, 11, 929. [CrossRef]

145. Antonetti, P.; Maklan, S. Feelings that make a difference: How guilt and pride convince consumers of the effectiveness of sustainable consumption choices. J. Bus. Ethics 2014, 124, 117-134. [CrossRef]

146. Wang, J.; Wu, L. The impact of emotions on the intention of sustainable consumption choices: Evidence from a big city in an emerging country. J. Clean. Prod. 2016, 126, 325-336. [CrossRef] 
147. de Medeiros, J.F.; Marcon, A.; Duarte Ribeiro, J.L.; Quist, J.; D'Agostin, A. Consumer emotions and collaborative consumption: The effect of COVID-19 on the adoption of use-oriented product-service systems. Sustain. Prod. Consum. 2021, 27, 1569-1588. [CrossRef]

148. Sun, X.; Su, W.; Guo, X.; Tian, Z. The impact of awe induced by COVID-19 pandemic on green consumption behavior in China. Int. J. Environ. Res. Public Health 2021, 18, 543. [CrossRef] 